IGUSABDER, 13 (2021): 1-15

\title{
BRCA1 ve BRCA2 Mutasyonlarının Tespitine Yönelik Yeni Nesil Dizileme Temelli Kit Geliştirilmesi ve Rutinde Kullanılan Yöntemler ile Valide Edilmesi*
}

\author{
Gözde GİRGIN ÖZGÜMÜŞ**, Ahmet İlter GÜNEY ${ }^{* * *}$
}

$\ddot{0} \mathbf{z}$

Amaç: Meme kanseri, kadınlarda en yaygın görülen kanser türü olup, Göğüs Kanseri Duyarlılık gen (BRCA1 ve BRCA2) mutasyonlarının meme ve yumurtalık kanserlerinin önemli bir kısmından sorumlu olduğu bilinmektedir. Bu genlerden birinde mutasyon taşıyan bireylerde yaşam boyu meme, yumurtalık, pankreas ve diğer kanserlere yakalanma riski oldukça yükselmektedir. BRCA1/2 gen mutasyonlarına sahip olan kişilerin belirlenmesi, genetik danışma ile tarama sıklığının artırılması ve potansiyel olarak hayat kurtaran önleyici tedavi stratejilerinin uygulanabilmesi için büyük önem taşımaktadır. Bu çalışmada gerçek zamanlı polimeraz zincir reaksiyonu (RT-PZR) yöntemi kullanılarak BRCA1/2 genlerinin yeni nesil dizi (NGS) analizi kütüphanelerinin hazırlanması ve NGS analizlerine uygun biyoinformatik iş akışının belirlenmesi amaçlanmıştır.

Yöntem: Rutin analizlerde yaygın olarak kullanılan Multiplicom BRCA MASTR ${ }^{\mathrm{TM}}$ Dx Kiti ile çalışılmış hastalardan alınan kan örneklerinden, DNA izolasyonu sonrası RT-PZR ile NGS kütüphanelerinin hazırlanması ve her bir örneğin 2 farklı etiket dizi ile işaretlenmesinin ardından NGS analizlerinin biyoinformatik iş akışlarının belirlenmesi gerçekleştirilmiştir.

\footnotetext{
Özgün Araştırma Makalesi (Original Research Article)

Geliş / Received: 19.12.2020 \& Kabul / Accepted: 14.01.2021

DOI: https://doi.org/10.38079/igusabder.843199

* Bu makale, Gözde GIRGIN ÖZGÜMÜ̈S’ün 2017 yllında Doç. Dr. Ahmet İlter GÜNEY'in danışmanlığında, Marmara Üniversitesi, Sağllk Bilimleri Enstitüsü, Tıbbi Biyoloji ve Genetik Anabilim Dalı'nda kabul edilmiş "BRCA1 ve BRCA2 Mutasyonlarının Tespitine Yönelik Yeni Nesil Dizileme Temelli Kit Geliştirilmesi ve Rutinde Kullanılan Yöntemler ile Valide Edilmesi” başlıklı doktora tezinden üretilmiştir.

** Dr., Marmara Üniversitesi, Sağlık Bilimleri Enstitüsü, Tıbbi Biyoloji ve Genetik Anabilim Dalı, İstanbul, Türkiye, E-posta: gozdegirgin85@gmail.com ORCID https://orcid.org/oooo-00o15401-9194

${ }_{* * * *}$ Doç. Dr., Marmara Üniversitesi, Tıp Fakültesi, Tıbbi Genetik Anabilim Dalı, İstanbul, Türkiye, E-posta: ilterg@hotmail.com ORCID https://orcid.org/o00o-0002-1661-1282
} 
Bulgular: Referans metoda göre test limitleri; \%10o duyarlılık, \%10o özgüllük ve \%10o doğruluk olarak belirlenmiştir. Wilson yöntemi kullanılarak testin güven aralı̆̆ CI: \%86-\%10o olarak hesaplanmıştır.

Sonuç: BRCA1 ve BRCA2 genlerinin klinik laboratuvarlar değerlendirmesine uygun verilerin elde edildiği, patojenik mutasyon tespitini yüksek verimlilik ve doğrulukla yapabilen uygun maliyetli bir NGS testinin geliştirilmesi ve analitik doğrulaması bu çalışma ile tamamlanmıştır.

Anahtar Sözcükler: Meme kanseri, BRCA1, BRCA2, yeni nesil dizileme, NGS kütüphane oluşturması.

\title{
Development of Next Generation Sequencing Based Kit for the Detection of BRCA1 and BRCA2 Mutations, and Validation With Routinely Used Methods
}

\begin{abstract}
Aim: Breast cancer is the most common type of cancer in women, and it is well known that Breast Cancer Susceptibility gene (BRCA1 and BRCA2) mutations are responsible for a substantial portion of the breast and ovarian cancers. Individuals carrying a mutation in one of these genes have an increased substantially lifelong risk of breast, ovarian, pancreatic, and other types of cancers. Identifying individuals with BRCA1/2 gene mutations is vital for increasing screening of family members via genetic counselling, and using potentially life-saving preventive measures. The aim of this study is preparation of next generation sequencing (NGS) libraries of BRCA1/2 genes using real time polymerase chain reaction (RT-PCR), and determination of bioinformatic workflow suitable for NGS analysis.

Methods: Using blood samples previously analyzed with Multiplicom BRCA MASTR ${ }^{\mathrm{TM}}$ Dx kit that is widely utilized in routine practice; DNA isolation was consequently followed by preparation of NGS libraries with RT-PCR, marking each sample with 2 different tag sequences, and determination of bioinformatic workflow for NGS analysis.

Results: Compared with the reference method, test limits were: 100\% sensitivity, 100\% specificity, and $100 \%$ validity. The confidence interval was calculated to be between 86 and 100\% using the Wilson method.

Conclusion: This study resulted in the successful development and analytic validation of a lowcost NGS test kit capable of accurately determining pathogenic mutations of BRCA1 and BRCA2 genes.
\end{abstract}

Keywords: Breast cancer, BRCA1, BRCA2, next generation sequencing, library preparation for NGS. 


\section{Giriş}

Kalıtsal meme ve yumurtalık kanseri sendromu (HBOC) tümör baskılayıcı genler olarak bilinen Göğüs Kanseri Duyarlılık genlerinde BRCA1 ve BRCA2'de bulunan mutasyonlarla ilişkilidir. Bundan dolayı ailesel olarak risk altında olan bireylerin genetik analizler ile tespiti geniş çapta kabul gören bir uygulamadır. Çeşitli meslek kuruluşları ve uzmanlarında yer aldı ̆̆ topluluklar BRCA1 ve BRCA2 mutasyon testlerinden kimlerin fayda görebileceğinin belirlenmesi ile ilgili klinik kriterleri ve uygulama kılavuzlarını hazırlamışlardır'-7. Genel olarak kişiye özel olarak belirlenen bu risk değerlendirmesi ve BRCA1/2 testi bireysel ve/veya ailesel meme, yumurtalık, pankreas, prostat kanseri öyküsü olan kişilere uygulanmaktadır. Çeşitli kılavuzların önerdiği gibi, BRCA1 ve BRCA2 mutasyonu tanımlanan kişilerde meme, yumurtalık, pankreas, prostat ve bazı diğer kanserler için hayat boyu karşılaşma riski, BRCA1 mutasyonu taşıyan kişilerde genel popülasyona göre \%50-80; BRCA2 mutasyonu taşıyan bireylerde \%40-70 oranında artmıştır7. BRCA1/2 mutasyonlarının taranması, meme ve yumurtalık kanserinin erken tanısı ve önlenmesi için büyük önem taşımaktadır8,9. Bu bağlamda arttırılmış taramalar, önleyici ilaç tedavileri ve hatta profilaktik cerrahi seçenekler arasında değerlendirilebilmektedir.

Amerikan Meme Cerrahları Derneği yüksek riskli popülasyonlardaki bireylerin rutin taranmasını önermektedir. Bu öneriye göre yüksek risk grubu; 50 yaşından önce meme kanseri tanısı almış olanları, birden çok meme kanseri primer odağı olanları, ailesinde erken yaşta meme kanseri öyküsü olanları, kendisi veya ailesinde yumurtalık kanseri öyküsü bulunanları, ailesinde BRCA1/2 mutasyonu tespit edilmiş olanları, 60 yaşından önce üçlü negatif meme kanseri tanısı alanları, ailede herediter meme veya yumurtalık kanseri ile birlikte pankreas kanseri teşhisi konulanları, erkek cinsiyete veya Askenazi ırkına ait bireyleri kapsamaktadır ${ }^{1-6}$.

Sanger dizileme tekniği in-vitro DNA replikasyonu esnasında ddNTP'ler ile zincir sonlanmasına dayanan bir yöntemdir. 3'-OH grubu olmayan ddNTP'ler, DNA polimeraz ile katalizlenen DNA uzamasını sonlandırırlar. PZR amplikonları kapiller sistemde yürürken floresan işaretine bağlı olarak, nükleotidler tanınır ve bu yöntem birinci nesil dizileme olarak bilinmektedir ${ }^{10}$. NGS teknolojileri ise, Sanger dizileme yöntemi gibi daha eski yaklaşımlar ile karşılaştırıldığında; çok daha hızlı, çok yüksek verimlilikle büyük 
verilerin elde edildiği ve düşük maliyetli yöntemlerdirrio,11. Günümüzde pek çok genetik laboratuvarında BRCA1/2 genlerindeki mutasyonların tanısal testi için bir NGS yaklaşımı veya BRCA1 ve BRCA2 genlerini içeren çok genli paneller uygulanmaktadır. Tamamen bağımsız ve kör değerlendirmeleri içeren NGS metodolojilerinin Sanger dizileme ile karşılaştırma çalışmalarını yapan araştırmacıların elde ettiği sonuçlar NGS teknolojileriyle elde edilen verilerin çok yüksek doğruluk ve duyarlılığa sahip olduğunu göstermektedir ${ }^{10-16}$. Bununla birlikte, numune hazırlama tekniklerindeki standardizasyon eksiklikleri, farklı platformlar ve farklı veri analiz yöntemleriyle elde edilen varyant sınıflandırmaları arasındaki farklılıklar, NGS platformunun klinik uygulamada kullanımına ilişkin zorluklar arasında yer almaktadır'16,17. Bundan dolayı optimize edilmiş ve doğrulanmış, analitik duyarlılık ve özgüllüğü maksimize edilmiş bir NGS test tasarımı klinik karar vermeyi kolaylaştırması bakımından önem kazanmaktadır.

Bu çalışmanın amacı BRCA1 ve BRCA2 genlerindeki mutasyonların mevcut testlere göre daha düşük maliyetle tespit edilebilmesine olanak sağlayan, NGS temelli, analitik duyarlılığı ve özgüllüğü yüksek, uluslararası standartlarda bir NGS kütüphane hazırlama kitinin geliştirilmesi, rutinde kullanılan testler ile doğrulanması ve elde edilen sonuçlarının yorumlanmasını kolaylaştıracak bir biyoinformatik analiz iş akışının belirlenmesidir.

\section{Gereç ve Yöntem}

\section{Çalışma Grubunun Belirlenmesi}

Çalışmada kullanılan 48 hasta örneğine ait DNA'lar yaştan bağımsız olarak, Marmara Üniversitesi Tıbbi Genetik Anabilim Dalında daha önce Illumina Miseq platformu kullanılarak Yeni Nesil Dizi Analizi yöntemiyle BRCA1/2 genlerine yönelik mutasyon analizi yapılmış hastalar arasından seçilmiştir. Çalışmanın etik açıdan uygunluğu, Marmara Üniversitesi Sağlık Bilimleri Enstitüsü Klinik Araştırmalar Ön Değerlendirme Komisyonu'nun 03.02.2017 tarihli Etik Komisyonunda incelenmiş ve 09.2017.119 numaralı dosya oy birliğiyle onaylanmıştır. 


\section{Kandan Genomik DNA İzolasyonu}

Tam kan örneklerinden DNA izolasyonu hızlı spin kolon yöntemiyle gerçekleştirildi ${ }^{18}$ ve elde edilen DNA örnekleri çalışılıncaya kadar $-45^{\circ} \mathrm{C}$ 'de saklandı. DNA örneklerinin saflık ve konsantrasyonlarının belirlenmesi için nano spektrofotometre Nanodrop ND-100o (Thermo Fisher Scientific, Waltham, MA) kullanılarak ölçüm yapıldı. DNA konsantrasyonu $(\mu \mathrm{g} / \mathrm{mL})=$ OD260 x 100 (dilüsyon faktörü) $\times 50 \mu \mathrm{g} / \mathrm{mL}$ ile hesaplandi ${ }^{19}$. Genomik DNA örneklerinin beklenen boyutta olup olmadığı ve degredasyonu agaroz jel elektroforezi yöntemi ile test edildi (Şekil 1). Referans olarak en büyük bandı 1,5 kb boyutunda olan DNA marker kullanılarak yapılan agaroz jel görüntüsünde seçilen 3 adet genomik DNA'nın boyutları görülmektedir.

Şekil 1: 3 Farklı Genomik DNA Örneğinin Agaroz Jel Görüntüsü

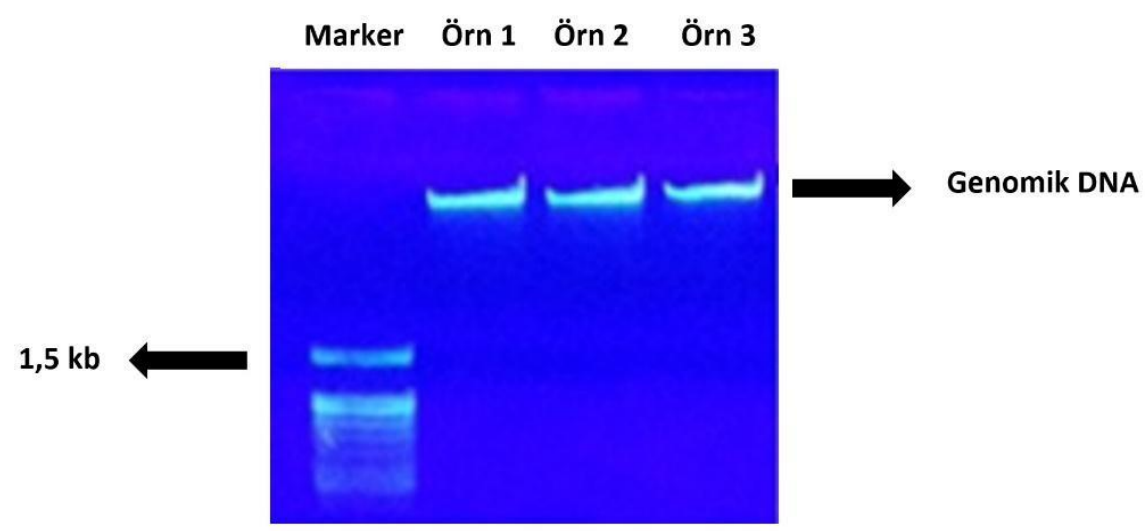

\section{Konnektör-Hedef Bölge Dizilerinin Tasarlanması ve Multipleks PZR Optimizasyonları}

BRCA1 ve BRCA2 genlerinin bütün ekzonları ve ekzon-intron sınırlarının çoğaltılması için kullanılacak olan hedef bölgeye özgü primer dizileri tasarlandı. chr17:43,044,29543,125,370 konumunda bulunan 81.076 baz çifti (bç) uzunluğunda, toplam 23 ekzondan oluşan BRCA1 geni (NCBI Reference Sequence: NM_o07294.2) ve chr13:32,315,48032,399,668 konumunda yer alan 84.189 bç uzunluğunda 27 ekzondan oluşan BRCA2 geni (NCBI Reference Sequence: NM_ooo059.3) referans dizileri kullanılarak tüm ekzon ve ekzon-intron sınırlarının çoğaltılması için ortalama uzunlukları yaklaşık 300400 bç olan gen bölgelerinin çoğaltılması amacıyla BRCA1 için 38; BRCA2 için ise 51 çift 
primer tasarlandı. Tasarımların ardından BRCA1 ve BRCA2 genlerinin multipleks 12 farklı reaksiyonda çalışabilen bir sistemi kuruldu ve multipleks gerçek zamanlı PZR çalışmaları için toplam reaksiyon hacmi $25 \mu$ lolarak belirlendi. Bu şekilde 96 kuyucuklu bir PZR plakasında 7 farklı örnek ve bir negatif kontrol reaksiyonu tek seferde çalışılabilir hale getirildi ve PZR reaksiyonları erime eğrisi analizine uygun şekilde gerçekleştirildi.

NGS Kütüphanelerin Oluşturulması, Mutasyonların Belirlenmesi ve Analizleri

Dizileme sonucu elde edilen veriler, varyasyonları ve mutasyonları değerlendirmek amaciyla NCBI (National Center for Biotechnology Information) ve ExAc (Exome Aggregation Consortium) veritabanlarında kontrol edildi. Bu çalışmaya dâhil edilen 48 hasta örneği Multiplicom BRCA MASTR ${ }^{\mathrm{TM}}$ Dx Kiti kullanılarak Illumina Miseq Platformunda dizilenip SOPHIA veri analiz programıla BRCA1/BRCA2 genlerinde mutasyon analizi yapıldı. Gene bu aynı 48 hasta örneği bu çalışma kapsamında geliştirilen multipleks kütüphane oluşturma yöntemiyle hazırlanıp Illumina Miseq platformunda dizi analizi gerçekleştirildi ve mutasyon analizleri Galaxy yazılım tabanlı bir biyoinformatik aracı ile tamamlandı.

\section{Biyoinformatik Akış Şeması}

Mutasyon analizleri için şu akış şeması oluşturuldu ve kullanıldı; Ham sekans dosyası

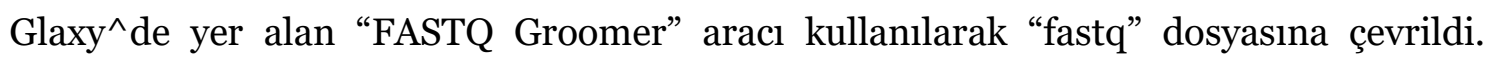
Çevrilen fastq dosyalarının kalite skoru "FastQC" aracı kullanılarak belirlendi. "Map with BWA-MEM" aracı kullanılarak haritalama yapıldı ve "SortSam" aracı ile dosyalar "SAM" dosyasına çevrildi. Elde edilen SAM dosyaları "Filter SAM" aracı ile filtrelenerek "BAM" dosyasına dönüştürmeye hazırlandı. "Mpileup" aracı kullanılarak dosyalar "BAM" dosyasına çevrildi ve VCF dosyası olarak kaydedildi. "SnpEFF" veya PROVEAN (Protein Variation Effect Analyzer) Human Genome Variants" aracı ile VCF dosyalarında listelenmiş olan varyantların anlamlandırılması ve klinik açıdan yorumlanması gerçekleştirildi. 


\section{Bulgular}

\section{BRCA1 ve BRCA2 Dizi Analizi Sonuçları}

Elde edilen ham verilerin kalite kontrolü sonucunda dizilerin ortalama kalitesi 39,1 olarak belirlendi. Analiz sonuçları tüm ekzonların en az 3oX kapsayıcılık ve 48 örneğin ortalama \%89'luk gibi yüksek bir eşleşme oranı ile haritalandığını göstermektedir. Tasarlanan NGS analiz yazılım paketi ile yürütülen analiz sonucunda SnpEff ile yapılan anotasyon değerlendirmesinden sonra örnek dizi verisinden elde edilen toplam 1210 (545 BRCA1 varyasyonu, 665 BRCA2 varyasyonu) varyasyonun, 379 tanesi homozigot, 831 tanesi heterozigot değişimler olarak belirlendi (Tablo 1). Tespit edilen BRCA1 mutasyonlarının 67 tanesi 3' çevrilmeyen bölgesinde (3' UTR), 13 tanesi 5' çevrilmeyen bölgesinde ( 5 ' UTR) ve 142 tanesi ekzonlara yakın intron bölgesinde görüldü. Bunların dışında yüksek etkili olarak kabul edilen; 56 çerçeve kayması mutasyonu (frameshift), 15 çerçeve içi delesyonu (in-frame deletion), 1 çerçeve içi insersiyonu (in-frame insersion), 12 uç birleştirme alıcı bölge mutasyonu (splicing acceptor side), 7 uç birleştirme verici bölge mutasyonu (splice donor side), 53 uç birleştirme bölge mutasyonu (splice region), 4 başlama kodonu kaybı, 20 sonlanma kodonu eklenmesi, 1 sonlanma kodonu kaybı ve 154 anlamsız mutasyon (missense) bulundu. Tespit edilen BRCA2 mutasyonlarının 10 tanesi 3' UTR bölgesinde, 10 tanesi 5' UTR bölgesinde ve 215 tanesi ekzonlara yakın intron bölgesinde görüldü. Bunların dışında yüksek etkili olarak kabul edilen; 98 çerçeve kayması mutasyonu, 30 tane çerçeve içi delesyonu, 4 çerçeve içi insersiyonu, 4 uç birleştirme alıcı bölge mutasyonu, 6 uç birleştirme verici bölge mutasyonu, 49 uç birleştirme bölge mutasyonu, 3 başlama kodonu kaybı, 33 sonlanma kodonu eklenmesi ve 203 anlamsız mutasyonu bulundu (Tablo 1). 
Tablo 1: BRCA1 ve BRCA2'de tespit edilen mutasyonlarının dağılımı

\begin{tabular}{|l|c|c|}
\hline Mutasyon Çeşitleri & BRCA1 & BRCA2 \\
\hline 3'UTR & 67 & 10 \\
\hline 5'UTR & 13 & 10 \\
\hline Ekzon-İntron Bağlantılarında & 142 & 215 \\
\hline Çerçeve Kayması & 56 & 98 \\
\hline Çerçeve İçi Delesyon & 15 & 30 \\
\hline Çerçeve İçi İnsersiyon & 1 & 4 \\
\hline Anlamsız Mutasyon & 154 & 203 \\
\hline Uç birleştirme Alıcı Bölge & 12 & 4 \\
\hline Uç birleştirme Verici Bölge & 7 & 6 \\
\hline Uç birleştirme Bölge & 53 & 49 \\
\hline Başlama Kodonu Kaybı & 4 & 3 \\
\hline Sonlanma Kodonu Eklenmesi & 20 & 33 \\
\hline Sonlanma Kodonu Kaybı & 1 & o \\
\hline Toplam & 545 & 665 \\
\hline
\end{tabular}

32 tanesi BRCA1 ve 37 tanesi BRCA2 geni ile ilişkili olan 69 farklı varyasyondan, ClinVar veri tabanında kayıtlı olan ve meme/over kanseri ile ilişkisi bulunan 66 tanesi tespit edildi. Çalışılan 48 örnekten 43 tanesinde BRCA1 polimorfizm ve mutasyonu saptanırken; 48 örneğin tamamında BRCA2 polimorfizm ve mutasyonlarına rastlandı. Tespit edilen 1210 varyasyonun 1093 tanesi polimorfizm; 117 tanesi mutasyon olarak kaydedildi.

Galaxy tabanlı yazılım ile değerlendirilen 48 hasta örneği için yaklaşık olarak \%20 daha fazla Tek Nükleotid Polimorfizmi (Single Nucleotide Polymorphism; SNP) tespit edildi. Şekil 2'de verilen Sophia ve Galaxy tabanlı yazılım analiz sonuç tablosuna göre Galaxy tabanlı yazılımın kapsayıcılığı Sophia'dan daha yüksek olarak tespit edildi.

“rs80358842” nolu patojenik varyant Galaxy tabanlı iş akışı ile tespit edilip Sophia analiz yazılımı ile tespit edilmedi. Bu durumun analiz yazılımlarının tespit hassasiyetinden mi 
yoksa hazırlanan kütüphanelerin kapsayıcılığından mı kaynaklandığının netleştirilebilmesi için belirtilen rs numarasının bulunduğu genin ekzonuna yönelik bir okuma primeri tasarlanarak hem Multiplicom BRCA MASTR ${ }^{\mathrm{TM}}$ Dx kiti hem de çalışma kapsamında geliştirilen yöntemle ilgili ekzonun çoğaltılıp Sanger dizi analizi gerçekleştirildi (Şekil 3). Sanger dizi analizi sonucuna göre BRCA2 geni ekzon 11'deki rs80358842 bölgesi her iki DNA Kütüphanesi içerisinde de yer almaktadır. Bu da geliştirilen analiz yazılım programının yüksek tespit gücü sayesinde Sophia yazılımı ile tespit edilememiş bir rs varyantını yakalamasını sağlamıştır. Bu durumu doğrulamak için Sophia yazılımı ile değerlendirilen ve Multiplicom BRCA MASTR ${ }^{\mathrm{TM}}$ Dx Kit ile hazırlanan kütüphanelerden elde edilen ham veriler bir kez de geliştirilen analiz yazılımı ile değerlendirildi ve sonuçta aynı DNA kütüphanesinden kapsayıcılı̆̆ı farklı SNP verileri elde edildiği görüldü. Galaxy (mavi) ve Sophia (turuncu) yazılımları ile yapılan analizler sonucu elde edilen varyant sayılarının karşılaştırma grafiğinde; bu çalışma kapsamında iş akışı belirlenen Galaxy tabanlı yazılımın tespit ettiği varyant sayılarının Sophia yazılımına göre daha yüksek olduğu görüldü (Şekil 2).

Şekil 2: Galaxy ve Sophia yazılımı karşılaştırmalı varyant sayıları

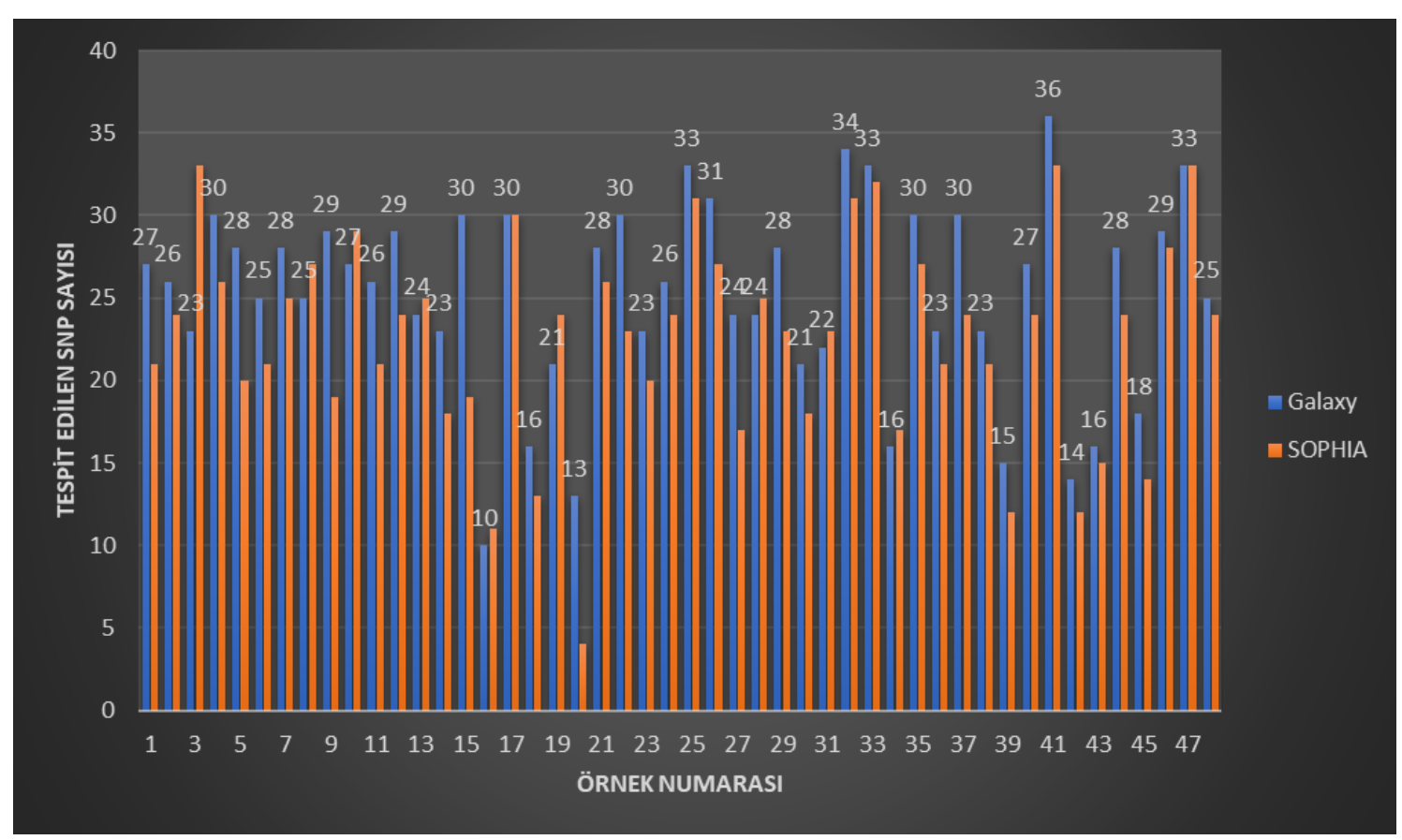

“rs80358842” numaralı NM_oooo58.3(BRCA2): c.6058G>T (p.Glu2020Ter) patojenik değişimi her iki DNA kütüphanesi içerisinde de yer almaktadır (Şekil 3). 
Şekil 3: BRCA2 geni ekzon11 rs80358842 bölgesi Sanger dizileme sonucu

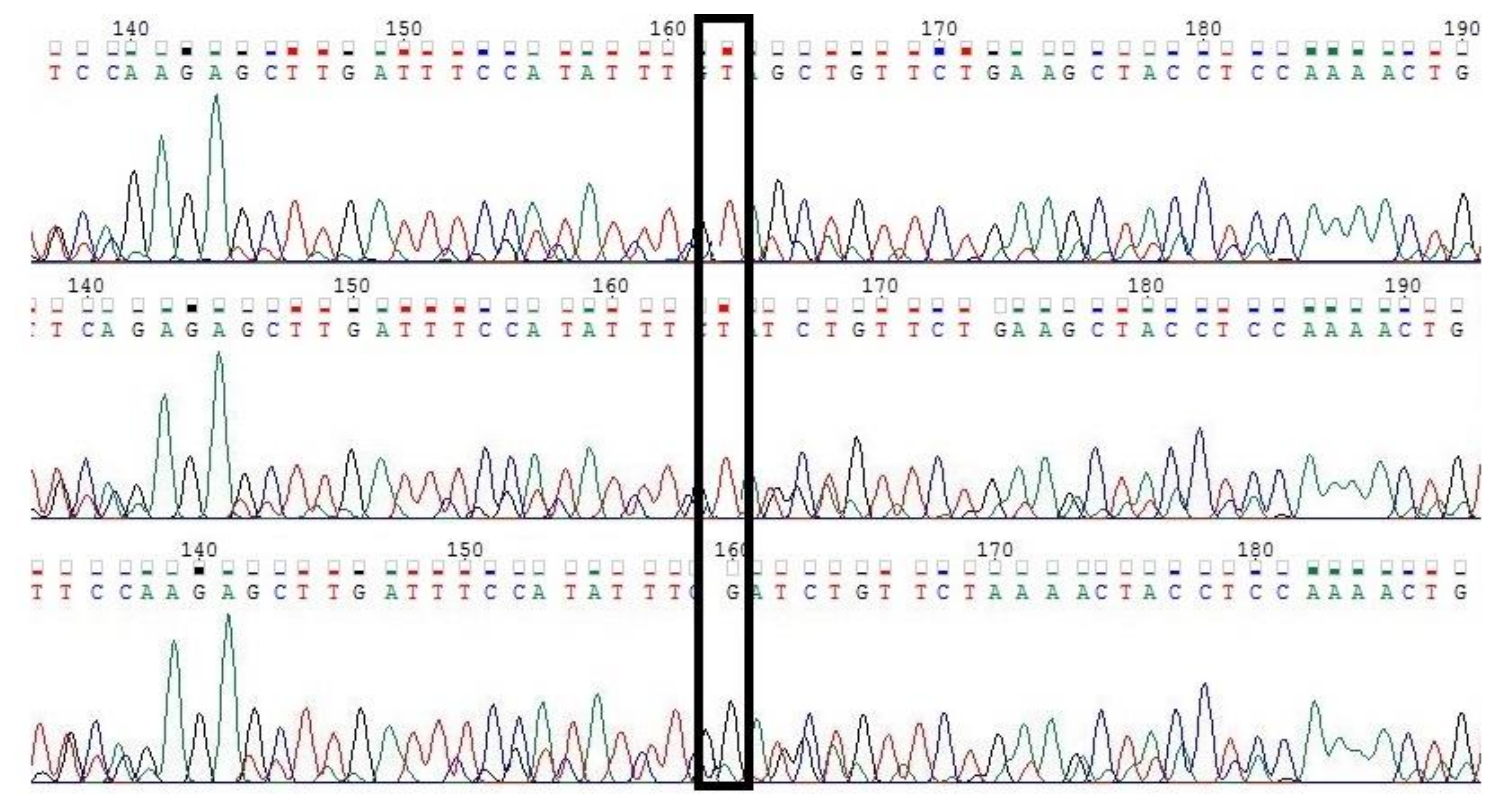

Güven seviyesi \%95, Türkiye’deki kadın popülasyon büyüklüğü 41.439 .462 olarak alındığında, Wilson (1927) yöntemi ${ }^{20}$ kullanılarak testin güven aralığı \%86-\%10o olarak hesaplandı.

Referans ve çalışma kapsamında geliştirilen yöntemler arasında uyumsuz olarak 11 adet meme kanseri ile ilişkili olduğu veri tabanında belirtilen rs numarasına sahip mutasyon tespit edildi ve Sanger dizileme yöntemiyle doğrulandı. Sanger dizileme ile de doğrulaması yapılan 1 adet patojenik varyasyon tespit edildi. Sonuçta validasyon çalışması yapılan test ile referans metotlara göre yanlış pozitif sonuç elde edilmediği gösterildi. Karşılaştırması yapılan 2 referans metoda göre elde edilen sonuçlarla \%100 duyarlılık, \%10o özgüllük ve \%10o doğrulukla testin limitleri belirlendi.

\section{Tartışma}

Meme kanseri, kadınlarda en yaygın görülen kanser türü olup BRCA1 ve BRCA2 mutasyonlarının meme ve over kanserlerinin önemli bir kısmından sorumlu olduğu bilinmektedir. BRCA1/2 gen mutasyonu taşıyıcılığının erken tespit edilmesinin genetik danışma alma, daha sık aralıklarla taramalara girme ve potansiyel olarak hayat kurtaran 
önleyici stratejilerden faydalanabilme gibi önemli avantajlar sağladığı ile ilgili kanttlar günümüzde yapılan çalışmalar ile artmaktadır ${ }^{8,9,11}$.

NGS teknolojisi, BRCA1 ve BRCA2 analizi de dâhil olmak üzere teşhis alanında giderek daha fazla uygulanmaktadır. Son yıllarda yapılan yayınlar kalıtsal kanser risk belirleme gen panellerinin hastalar arasındaki mutasyon prevalansının belirlenmesi için kullanımın arttığını göstermektedir21-25. Yaptığımız çalışmadan elde edilen yüksek duyarlılık ve özgüllük sonuçları daha önce yapılan benzer çalışma sonuçları ile uyumlu sonuçlar vermiştirir1214-16. Bununla beraber yaptığımız çalışma sonucunda elde edilen yanlış pozitif oranları daha önce yapılan benzer çalışma oranlarından düşük olarak belirlenmiştir ve günümüzde yapılan pek çok çalışma ile NGS sonuçlarının Sanger dizi analizi sonuçlarıyla eşdeğer sonuçlar verdiği belirlenmiştiri3,26-29.

Çalışmanın bazı sınırlayıcı noktaları bulunmaktadır. İlk olarak tüm çalışma tam kan numunelerinden elde edilen nükleik asit kullanılarak çalışıldı. Bu durum testin uygulanmasında kullanılabilecek örnek tipini sınırlamaktadır. Ayrıca derin intronik sekans değişimleri gibi nadir varyasyonlar ve genomik inversiyon gibi büyük yeniden düzenlenmelerin primer bağlanma bölgelerine denk gelme durumunda, PZR tabanlı amplikon zenginleştirme yaklaşımı ile tespit edilemeyebilir.

Çalışma kapsamında geliştirilen NGS verilerinin analiz yazılımı piyasada sıkça kullanılan ve dünya genelinde yaygın kullanılan bir yazılıma göre valide edildi. İş akışları son kullanıcıya değerlendirme aşamasında kolaylık sağlayacak şekilde, kullanıcı dostu bir ara yüze sahip olması ile biyoinformatik araçlara kendisini yabancı hisseden kullanıcılara bile kullanım kolaylı̆̆ı sağlaması amaçlandı. Bu sayede NGS çalışmalarının yaygınlaşması ve gelecek yıllarda elde edilen verilerin çoğalması ile hastalık ilişkili popülasyon verilerinin artarak veri tabanlarının oluşturulmasına katkı sağlaması amaçlandı.

Çalışma kapsamında 48 hasta örneği kullanılarak elde edilen ham verilerle yapılan analizler sonucunda her iki yazılım karşılaştırıldığında geliştirilen ve BioGalVCF olarak adlandırılan yazılımın aynı örnek amplikon kütüphaneleri üzerinde SOPHIA yazılımına göre daha kapsayıcı sonuçlar verdiği gözlemlendi. BioGalVCF hem zaman açısından hem de bilgisayar ara yüz kullanımı açısından da daha avantajlı olduğu değerlendirildi. 


\section{Sonuç}

Erken tanı açısından; hızlı, ucuz ve doğru bir şekilde test edilebilmesi büyük önem taşıyan BRCA1 ve BRCA 2 genlerinin klinik laboratuvar değerlendirmesine uygun verilerin elde edildiği, patojenik mutasyon tespitini yüksek verimlilik ve doğrulukla yapabilen, uygun maliyetli bir NGS testinin geliştirilmesi ve analitik doğrulaması bu çalışma ile tamamlanmıştır. Geliştirilen NGS temelli, uluslararası standartlarda kit ile elde edilen sonuçların değerlendirilmesini kolaylaştıran bir analiz yazılımı iş akışı da çalışmamız kapsamında geliştirilmiş ve doğrulanmıştır. Böylece düşük maliyet, yüksek okuma doğruluğu, kolay uygulanabilirlik, hızlı ve güvenilir sonuçlar, tekrarlanabilirlik ve anlaşılır, uygulanabilir biyoinformatik analiz yazılım iş akışı şeması ortaya koyulmuştur. Bu çalışma kapsamında geliştirilen testin klinik laboratuvarlar için gerekli olan kalite standartlarını ve daha önce ortaya konmuş olan kriterleri karşıladığı görülmüştür3o.

\section{KAYNAKLAR}

1. Robson ME, Storm CD, Weitzel J, Wollins DS, Offit K. American Society of Clinical Oncology policy statement update: genetic and genomic testing for cancer susceptibility. J Clin Oncol. 2010;28(5):893-901.

2. Statement of the American Society of Human Genetics on genetic testing for breast and ovarian cancer predisposition. Am J Hum Genet. 1994;55(5):i-iv.

3. Hampel H, Bennett RL, Buchanan A, Pearlman R, Wiesner GL. A practice guideline from the American College of Medical Genetics and Genomics and the National Society of Genetic Counselors: referral indications for cancer predisposition assessment. Genet Med. 2015;17(1):70-87.

4. Nelson HD, Pappas M, Zakher B, Mitchell JP, Okinaka-Hu L, Fu R. Risk assessment, genetic counseling, and genetic testing for BRCA-related cancer in women: a systematic review to update the U.S. Preventive Services Task Force recommendation. Ann Intern Med. 2014;160(4):255-266.

5. Lancaster JM, Powell CB, Kauff ND, et al. Society of Gynecologic Oncologists Education Committee statement on risk assessment for inherited gynecologic cancer predispositions. Gynecol Oncol. 2007;107(2):159-162. 
6. Balmaña J, Díez O, Rubio IT, Cardoso F. BRCA in breast cancer: ESMO Clinical Practice Guidelines. Ann Oncol. 2011;22(Suppl 6):31-34.

7. Petrucelli N, Daly MB, Pal T. BRCA1- and BRCA2-Associated Hereditary Breast and Ovarian Cancer. In: Adam MP, Ardinger HH, Pagon RA, et al., eds. GeneReviews®. Seattle (WA): University of Washington, Seattle;1998.

8. Tung NM, Garber JE. BRCA1/2 testing: therapeutic implications for breast cancer management. Br J Cancer. 2018;119(2):141-152.

9. Solmaz AE, Onay H, Yeniay L, et al. BRCA1-BRCA2 mutation analysis results in 910 individuals: Mutation distribution and 8 novel mutations. Cancer Genet. 2020;241:20-24.

10. Heather JM, Chain B. The sequence of sequencers: The history of sequencing DNA. Genomics. 2016;107(1):1-8.

11. Qin D. Next-generation sequencing and its clinical application. Cancer Biol Med. 2019;16(1):4-10.

12. Bosdet IE, Docking TR, Butterfield YS, et al. A clinically validated diagnostic second-generation sequencing assay for detection of hereditary BRCA1 and BRCA2 mutations. J Mol Diagn. 2013;15(6):796-809. doi: 10.1016/j.jmoldx.2013.07.004

13. Chong HK, Wang T, Lu HM, et al. The validation and clinical implementation of BRCAplus: a comprehensive high-risk breast cancer diagnostic assay. PLoS One. 2014;9(5):e97408.

14. Judkins T, Leclair B, Bowles K, et al. Development and analytical validation of a 25-gene next generation sequencing panel that includes the BRCA1 and BRCA2 genes to assess hereditary cancer risk. BMC Cancer. 2015;15:215.

15. Lincoln SE, Kobayashi Y, Anderson MJ, et al. A systematic comparison of traditional and multigene panel testing for hereditary breast and ovarian cancer genes in more than 1000 patients. The Journal of Molecular Diagnostics: JMD. 2015;17(5):533-544.

16. Strom CM, Rivera S, Elzinga C, et al. Development and validation of a nextgeneration sequencing assay for BRCA1 and BRCA2 variants for the clinical laboratory. PLoS One. 2015;10(8):e0136419. 
17. Yoonjung Kim, Chi-Heum Cho, Jung-Sook Ha, et al. An optimized BRCA1/2 next-generation sequencing for different clinical sample types. J Gynecol Oncol. 2020;31(1):e9.

18. Chacon-cortes D, Griffiths L, Chacon-Cortes D. Methods for extracting genomic DNA from whole blood samples: current perspectives. Journal of Biorepository Science for Applied Medicine. 2014;2:1-9.

19. Montgomery J, Wittwer CT, Palais R, Zhou L. Simultaneous mutation scanning and genotyping by high-resolution DNA melting analysis. Nat Protoc. 2007;2(1):59-66.

20. Wilson JR, Bateman AC, Hanson H, et al. A novel HER2-positive breast cancer phenotype arising from germline $\mathrm{TP}_{53}$ mutations. $J$ Med Genet. 2010;47(11):771-774.

21. Tung N, Battelli C, Allen B, et al. Frequency of mutations in individuals with breast cancer referred for BRCA1 and BRCA2 testing using next-generation sequencing with a 25-gene panel. Cancer. 2015;121(1):25-33.

22. Hiraki S, Rinella ES, Schnabel F, Oratz R, Ostrer H. Cancer risk assessment using genetic panel testing: considerations for clinical application. $J$ Genet Couns. 2014;23(4):604-617.

23. Kurian AW, Hare EE, Mills MA, et al. Clinical evaluation of a multiple-gene sequencing panel for hereditary cancer risk assessment. J Clin Oncol. 2014;32(19):2001-2009.

24. Nagahashi M, Shimada Y, Ichikawa H, et al. Next generation sequencing-based gene panel tests for the management of solid tumors. Cancer Sci. 2019;110(1):6-15.

25. Chen M, Zhao H. Next-generation sequencing in liquid biopsy: cancer screening and early detection. Hum Genomics. 2019;13:34-43.

26. Catana A, Apostu AP, Antemie RG. Multi gene panel testing for hereditary breast cancer - is it ready to be used? Med Pharm Rep. 2019;92(3):220-225.

27. Ladd MK, Peshkin BN, Isaacs C, et al. Predictors of genetic testing uptake in newly diagnosed breast cancer patients. J Surg Oncol. 2020;122(2):134-143. 
28. Kang HP, Maguire JR, Chu CS, et al. Design and validation of a next generation sequencing assay for hereditary BRCA1 and BRCA2 mutation testing. PeerJ. 2016;4:e2162.

29. Beck TF, Mullikin JC, Biesecker LG. Systematic evaluation of sanger validation of next-generation sequencing variants. Clinical Chemistry. 2016;62(4):647654 .

30. Rehm HL, Bale SJ, Bayrak-Toydemir P, et al. ACMG clinical laboratory standards for next-generation sequencing. Genet Med. 2013;15(9):733-747. 